Jean Marc Bernard MD, Michel Pinaud MD, Sylvie Carteau MD, Christophe Hubert MD, Rémi Souron MD

\title{
Hypotensive actions of diltiazem and nitroprusside com- pared during fentanyl anaesthesia for total hip arthroplasty
}

The potential for inducing hypotension during fentanyl anaesthesia by administering either diltiazem ( $n=7)$ or sodium nitroprusside $(n=7)$ was investigated during total hip arthroplasty. Haemodynamic variables were obtained in the lateral position before, during and after administration of the hypotensive agent. Diltiazem 0.15 $m g \cdot \mathrm{kg}^{-I}$ given as an $\mathrm{IV}$ bolus followed by a $12.5 \pm$ $3 \mu \mathrm{g} \cdot \mathrm{kg}^{-1} \cdot \mathrm{min}^{-1}$ continuous infusion decreased mean arterial pressure (MAP) from $77 \pm 11 \mathrm{mmHg}$ to $63 \pm 16$ $\mathrm{mmHg}(p<0.05)$ while other haemodynamic parameters showed only minor and insignificant changes. Hypotension continued for at least 30 min after the cessation of diltiazem. With sodium nitroprusside MAP decreased immediately from $81 \pm 11 \mathrm{mmHg}$ to $59 \pm 9 \mathrm{mmHg}(p<$ $0.01)$ and rapidly returned to its control value after cessation of the infusion. Cl and $Q s / Q t$ rose significantly $(p<0.05)$ while the systemic vascular resistance index (SVRI) $(p<0.01)$ and pulmonary vascular resistance index $(P V R I)(p<0.05)$ fell significantly. The haemo-

\section{Key words}

BLOOD PRESSURE: drug effects, calcium channel blockers, diltiazem, sodium nitroprusside; ANAESTHETIC TECHNIQUES: hypotension, induced, nitroprusside, diltiazem.

From the Départment d'Anesthésiologie, Centre Hospitalier Universitaire, Hotel-Dieu, 44035 Nantes, Cedex, France, where correspondence should be addressed to Dr. Pinaud.

This work was supported in part by the University of Nantes Institutional Grants Program, and in part by INSERM (Institut National de la Santé et de la Recherche Médicale) Contract number 825019. dynamic profile was significantly different between hypatensive agents for MAP $(p<0.02)$, heart rate $(H R)$ $(p<0.01)$, SVRI $(p<0.05)$, and PVRI $(p<0.05)$. HR was lower with diltiazem than with nitroprusside. A bradycardia less than 50 beats/min was observed in five patients in the diltiazem group. MAP, SVRI and PVRI were lower with nitroprusside than with diltiazem. Diltiazem can induce and maintain moderate hypotension without tachycardia and decreased cardiac output in humans during fentanyl anaesthesia but the modulation of the level of arterial pressure and the depression of atrioventricular conduction are unpredictable.

The anticipated benefits of moderate controlled hypotension during total hip arthroplasties no longer have to be demonstrated. ${ }^{1,2}$ Sodium nitroprusside (SNP) is the reference pharmacological agent ${ }^{3}$ but its side effects of potential toxicity, ${ }^{4}$ reflex activation of the sympathetic system, ${ }^{5}$ and hypertensive rebound on withdrawal ${ }^{6}$ encourage research on other controlled hypotension protocols. The literature provides little information about the use of calcium channel blockers to produce hypotension ${ }^{7}$ despite their well known vasodilator effects. ${ }^{8}$ Cottrel et al. investigated the effect of nifedipine as an IV bolus on systemic haemodynamics and intracranial pressure in the cat. ${ }^{9}$ Oates compared the hypotensive actions of SNP and verapamil infusions in the cat. ${ }^{10}$ Zimpfer et al. evaluated the haemodynamic effects of an IV bolus injection of verapamil during neuroleptanaesthesia in man in order to reduce impedance to ventricular ejection during the surgical procedure. " The potential for inducing hypotension by administering 
diltiazem intravenously was investigated in the dog under either halothane anaesthesia, ${ }^{12}$ or fentanyl anaesthesia. ${ }^{13,14}$ Diltiazem has not been tested in patients, ${ }^{15}$ since it has been feared that, like verapamil, it might lower arterial pressure by the preponderant lowering of cardiac output. Nifedipine acts more by the lowering of systemic vascular resistance. ${ }^{16}$

This investigation was designed to compare diltiazem with nitroprusside in producing controlled hypotension during total hip arthroplasty and to determine the haemodynamic profiles produced.

\section{Methods}

Fourteen patients (ten women and four men), with a mean age of 65 years (range: 48 to 77), had total hip arthroplasties (prosthesis Charnley-Kerboull type), under general anaesthesia.

After premedication (15 $\mathrm{mg}$ diazepam po), the patients were taken to the pre-anaesthesia room. Heart rate (HR) was monitored by a CMS lead. An 18 Gauge Teflon catheter was placed in a radial artery to measure systolic (SAP) and diastolic (DAP) arterial pressures. A $7 \mathrm{~F}$ thermodilution catheter was placed via the right jugular vein to measure right atrial pressure (RAP), systolic (SPAP) and diastolic (DPAP) pulmonary arterial pressures, pulmonary capillary wedge pressure (PCWP) and cardiac output (CO) (iced injectate in triplicate). Heart rate and pressure were simultaneously recorded on a multi-channel recorder (Mingograf 803 Siemens Elema). Standard formulae were used to calculate mean arterial pressure: MAP $=($ SAP - DAP $) / 3+$ DAP, cardiac index: CI $=\mathrm{CO} / \mathrm{BSA}$, stroke index: $\mathrm{SI}=\mathrm{CI} / \mathrm{HR}$, systemic vascular resistance index: SVRI $=($ MAP - RAP $)$ l $\mathrm{CI} \times 80$, and pulmonary vascular resistance index PVRI $=($ MPAP - PCWP $) / C I \times 80$.

$\mathrm{PO}_{2}, \mathrm{PCO}_{2}$ (ABL 30 acid-base analyzer radiometer), $\mathrm{SO}_{2}$ and haemoglobin concentration $\mathrm{OSM}_{2}$ hemoximeter radiometer) were measured in arterial blood and in mixed venous blood. The arterial $\left(\mathrm{CaO}_{2}\right)$, mixed venous $\left(\mathrm{C} \mathrm{CO}_{2}\right)$ and capillary $\left(\mathrm{CcO}_{2}\right)$ contents were calculated using the usual formulae: oxygen content $=\left(\mathrm{SO}_{2} \times \mathrm{Hb} \times 1.34\right)+\mathrm{PO}_{2} \times$ 0.003 , assuming $\mathrm{PcO}_{2}=\mathrm{PAO}_{2}$ and $\mathrm{ScO}_{2}=100$ per cent. The intrapulmonary shunt was calculated according to the formula: $\mathrm{Qs} / \mathrm{Qt}=\mathrm{CcO}_{2}-\mathrm{CaO}_{2} /$ $\mathrm{CcO}_{2}-\mathrm{Cu}_{2}$.

Patients were anaesthetized with thiopentone
( $5 \mathrm{mg} \cdot \mathrm{kg}^{-1}$ ) and fentanyl $\left(5 \mu \mathrm{g} \cdot \mathrm{kg}^{-1}\right)$, intubated after pancuronium injection $\left(0.1 \mathrm{mg} \cdot \mathrm{kg}^{-1}\right)$ and mechanically ventilated. Anaesthesia was maintained with oxygen in nitrous oxide $\left(\mathrm{FIO}_{2}: 0.5\right)$. The initial adjustments were adapted to maintain a $\mathrm{PaCO}_{2}$ between 4.5 and $5.2 \mathrm{kPa}(35-40 \mathrm{mmHg})$, with a respiratory frequency of 16 per minute and an $\mathrm{I} / \mathrm{E}$ ratio $=1 / 2$. Reinjections of fentanyl and pancuronium were systematic, while atropine was not given $(0.5 \mathrm{mg}$ IV) unless the HR was less than 50 per minute.

\section{Protocol}

An initial measurement of arterial pressure was obtained before anaesthesia in order to define the desired level of hypotension. The aim was to obtain moderate hypotension, equal to 50 per cent of the MAP of the patient when awake, without going below $55 \mathrm{mmHg}$. Patients were randomly divided into two groups: sodium nitroprusside $(\mathrm{n}=7)$ and diltiazem ( $n=7$ ). The hypotensive agent was perfused using a teflon antecubital catheter. The infusion rate of SNP (concentration $200 \mathrm{mg} \cdot \mathrm{L}^{-1}$ ) was regulated from 1 to $6 \mu \mathrm{g} \cdot \mathrm{kg}^{-1} \cdot \mathrm{min}^{-1}$ to achieve the desired hypotension. After the standardized injection of $0.15 \mathrm{mg} \cdot \mathrm{kg}^{-1}$ of diltiazem during one

TABLE I Basic patient data (mean values \pm SD)

\begin{tabular}{|c|c|c|}
\hline & \multicolumn{2}{|l|}{ Patient groups } \\
\hline & $\begin{array}{l}\text { Diltiazem } \\
(n=7)\end{array}$ & $\begin{array}{l}\text { Nitroprusside } \\
(n=7)\end{array}$ \\
\hline Age (years) & $65.4 \pm 9.1$ & $65.8 \pm 8.4$ \\
\hline Weight (kg) & $61.7 \pm 12.1$ & $62.9 \pm 13.8$ \\
\hline Sex & $5 F ; 2 M$ & $5 F ; 2 M$ \\
\hline $\begin{array}{l}\text { Duration of operation } \\
\text { (min) }\end{array}$ & $110 \pm 17$ & $95 \pm 18$ \\
\hline $\mathrm{PaCO}_{2}(\mathrm{kPa})$ & $4.8 \pm 0.4$ & $4.8 \pm 0.4$ \\
\hline $\mathrm{pH}$ & $7.44 \pm 0.04$ & $7.43 \pm 0.04$ \\
\hline $\begin{array}{l}\text { Fentanyl dose }\left(\mu \mathrm{g} \cdot \mathrm{kg}^{-1}\right) \\
\text { at incision } \\
\text { before first cementing }\end{array}$ & $\begin{array}{l}10.4 \pm 2.4 \\
17.9 \pm 3.2\end{array}$ & $\begin{array}{l}10.5 \pm 2.3 \\
17.3 \pm 3.2\end{array}$ \\
\hline $\begin{array}{l}\text { Volume expansion (ml) } \\
\text { fresh frozen plasma } \\
\text { packed red cells }\end{array}$ & $\begin{array}{l}1500 \pm 500 \\
1100 \pm 600\end{array}$ & $\begin{array}{r}1650 \pm 900 \\
800 \pm 600\end{array}$ \\
\hline $\begin{array}{c}\text { Postoperative } \\
\text { hematocrit }\end{array}$ & $36.4 \pm 1.7$ & $36.1 \pm 1.9$ \\
\hline
\end{tabular}

Non-paired $t$ test: NS. 


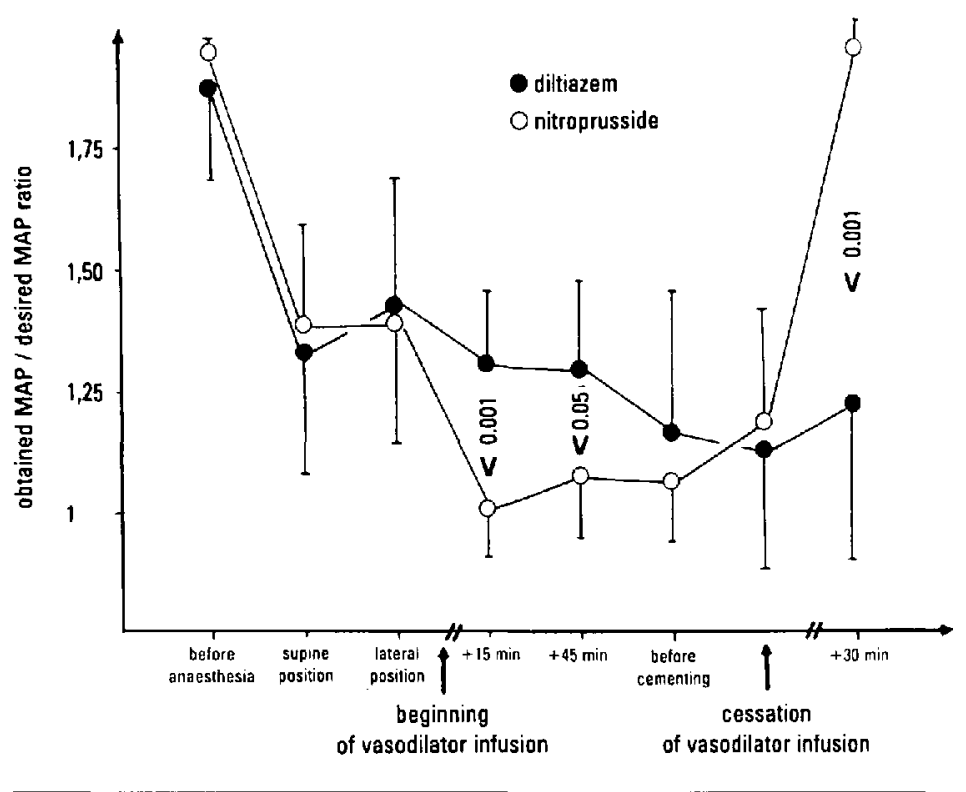

FIGURE Eyolution of the ratio MAP obtained/MAP desised throughout the study. The ratio was one when the goal (a 50 per cent decrease in MAP) was obtained. As the desired MAP was 50 per cent of the MAP of the patient when awake, the ratio was two before and after hypotension.

minute, the further infusion (rate about $5 \mu \mathrm{g} \cdot \mathrm{kg}^{-1}$. $\min ^{-1}$ ) was then regulated according to the pressure result obtained. The overall haemodynamic data and the ratio MAP obtained/MAP desired were recorded once the patient was asleep, in the supine position and then in the lateral position, prior to the administration of the hypotensive agent, during its administration (15th and 45th minutes of hypotension, before the first cementing and cessation of the product), and 30 minutes after stopping its administration. Fresh frozen plasma was perfused into a peripheral vein in order to maintain PCWP in the range 8-12 $\mathrm{mmHg}$; red blood cells were begun when blood loss was greater than $300 \mathrm{ml}$. The intrapulmonary shunt was calculated in the lateral position prior to the administration of the hypotensive agent, 15 minutes after the beginning of its administration, and then before the first cementing.

The haemodynamic data are expressed as means \pm SD. Statistical analysis was done using ANOVA in order to test the haemodynamic profile within each group; when the variance was significant, a paired $t$ test was used to assess the significance of the changes over time. The analysis of variance then permitted the difference between the two hypotension methods to be determined; when the variance was significant, an unpaired $t$ test was used to localise the difference. Finally, the variance analysis permitted an investigation of interference. Significance was assumed at $\mathrm{p}$ values less than 0.05 .

\section{Results}

Some general information is summarized in Table I. There were no significant differences between the two groups of patients.

The course of the MAP during the investigation is given in Table II. The desired lowering of pressure was identical for both groups $(-46.1 \pm 6.4$ per cent in the diltiazem group and $-48 \pm 1.5$ per cent in the nitroprusside group). The figure shows the course of the ratio MAP obtained/MAP desired. A decrease in this ratio was produced by the anaesthetic itself and the changes of body position. With nitroprusside, the desired level of hypotension was reached immediately and was maintained until the first cementing. With diltiazem, the objective was 
TABLE II Course of mean arterial pressure (mean \pm SD)

\begin{tabular}{|c|c|c|}
\hline \multirow[b]{2}{*}{ Time } & \multicolumn{2}{|c|}{ Patient groups } \\
\hline & $\begin{array}{l}\text { Diliazem } \\
(n=7)\end{array}$ & $\begin{array}{l}\text { Nitro- } \\
\text { prusside } \\
(n=7)\end{array}$ \\
\hline Supine position when awake & $106 \pm 13$ & $114 \pm 16$ \\
\hline Desired hypotension & $56 \pm 2$ & $56 \pm 7$ \\
\hline $\begin{array}{l}\text { Supine position when } \\
\text { anaesthetized }\end{array}$ & $71 \pm 17$ & $84 \pm 25$ \\
\hline $\begin{array}{l}\text { Lateral position when } \\
\text { anaesthetized }\end{array}$ & $77 \pm 17$ & $81 \pm 11$ \\
\hline Vasodilator $+15 \mathrm{~min}$ & $73 \pm 10$ & $59 \pm 9^{* *}$ \\
\hline Vasodilator $+45 \mathrm{~min}$ & $72=12$ & $63 \pm 9^{*}$ \\
\hline $\begin{array}{l}\text { Vasodilator prior to first } \\
\text { cement }\end{array}$ & $66 \pm 17$ & $62 \pm 9 t$ \\
\hline $\begin{array}{l}\text { Before cessation of } \\
\text { vasodilator }\end{array}$ & $63 \pm 16^{*}$ & $70 \pm 17$ \\
\hline $\begin{array}{l}\text { Cessation of vasodilator }+ \\
30 \mathrm{~min}\end{array}$ & $68 \pm 16$ & $114 \pm 12^{* *}$ \\
\hline $\mathrm{F}$ & 5.44 & 17.86 \\
\hline $\mathbf{p}$ & 0.001 & 0.001 \\
\hline
\end{tabular}

Significant differences within groups: paired $t$ test; $v s$ lateral position when anaesthetized, ${ }^{*} p<0.05 ; \nmid p<0.02 ;{ }^{*} p<0.01$. Significant differences between groups: non-paired t test; vasodilator +15 min: $p<0.05$; cessation of vasodilator $+30 \mathrm{~min}$ : $\mathrm{p}<0.02$.

reached only for the latest points (prior to cementing and before cessation of the infusion), after having doubled, even tripled, the infusion flow (overall dose: $1.125 \pm 0.250 \mathrm{mg} \cdot \mathrm{kg}^{-1}$; mean dosage: 12.5 $\left.\pm 3 \mu \mathrm{g} \cdot \mathrm{kg}^{-1} \cdot \mathrm{min}^{-1}\right)$. Furthermore, the diltiazem infusion had to be stopped on three occasions due to excessive hypotension. Blood pressure rose immediately after the cessation of nitroprusside, while hypotension continued for at least $30 \mathrm{~min}$ after the cessation of diltiazem (cessation +60 minutes: $\mathrm{MAP}=76 \pm 16 \mathrm{mmHg}$ ).

The haemodynamic course and the intrapulmonary shunt values during the diltiazem infusion are given in Table III, and the corresponding results for the nitroprusside group are given in Table IV. Although none of the parameters studied changed significantly in the diltiazem group, bradycardias of less than 50 beats/min required atropine injections in five of the seven patients; a junctional bradycardia persisted in two of these five patients and diltiazem was then stopped. With sodium nitroprusside, CI and Qs $/ Q t$ rose significantly $(p<0.05$ ), while the SVRI $(p<0.01)$ and PVRI $(p<0.05)$ fell significantly.

The time course of changes was significantly different between the hypotensive agents for MAP $(p<0.02)$, HR $(p<0.01)$, SVRI $(p<0.05)$, and PVRI ( $\mathrm{p}<0.05$ ). MAP was significantly lower with nitroprusside than with diltiazem at 15 minutes ( $p<0.05$ ) and significantly higher with nitroprusside than with diltiazem $30 \mathrm{~min}$ after cessation of the vasodilator $(p<0.02$ ) (Table II). HR was significantly lower with diltiazem than with nitroprusside at 45 minutes $(p<0.05)$, and before the first cementing $(p<0.02$ ). The SVRI and PVRI were significantly lower with nitroprusside than with diltiazem at 45 minutes $(p<0.05)$ and before cementing ( $p<0.05$ ).

A significant interaction existed between the use of nitroprusside or diltiazem and the overall course of MAP $(p<0.001)$ and SVRI $(p<0.05)$.

\section{Discussion}

In terms of handling or efficacy diltiazem is not comparable to sodium nitroprusside as a controlled hypotension agent for use in anaesthesia. The choice of the initial dosage (IV bolus of 0.15 $\mathrm{mg} \cdot \mathrm{kg}^{-1}$ followed by a continuous infusion of 5 $\mu \mathrm{g} \cdot \mathrm{kg}^{-1} \cdot \mathrm{min}^{-1}$ ) which was as a result of the work of Valette et al. ${ }^{17}$ led to a weak and inconsistent drop in blood pressure. The corresponding plasma levels reported by Valette et al. ${ }^{17}\left(145 \mathrm{ng} \cdot \mathrm{ml}^{-1}\right.$ after 20 minutes, and $321 \mathrm{ng} \cdot \mathrm{ml}^{-1}$ after 45 minutes) are nonetheless within the range of therapeutic efficacy. ${ }^{18-20}$ The effect of under-dosage seems to have been avoided since the dosage was doubled, even tripled, during the procedure. Significant hypotension was obtained only after the 60th minute, but there were considerable individual variations. In some cases hypotension did not occur while in others hypotension was too severe. The hypotensive effect was accentuated as time passed, contrary to the study of Pierrot et al. (bolus IV of $0.15 \mathrm{mg} \cdot \mathrm{kg}^{-1}$ followed by a continuous infusion of $1 \mu \mathrm{g} \cdot \mathrm{kg}^{-1} \cdot \mathrm{min}^{-1}$ ) in which the effect decreased with time. ${ }^{21}$ Finally, the hypotensive effect was prolonged for at least 60 minutes after cessation of the infusion, in agreement with Bourassa et al. ${ }^{22}$ While the persistence of this hypotension before closing of superficial layers may be considered to be harmful, the postoperative course was comparable in both groups. 
TABLE III Haemodynamic course during diltiazem infusion (mean values \pm SD)

\begin{tabular}{|c|c|c|c|c|c|c|}
\hline & \multirow[b]{2}{*}{$\begin{array}{l}\text { Baseline } \\
\text { (lateral } \\
\text { position) }\end{array}$} & \multicolumn{5}{|c|}{ Diltiazem infusion } \\
\hline & & $+15 \min$ & $+45 \min$ & $\begin{array}{l}\text { Before } \\
\text { cementing }\end{array}$ & $\begin{array}{l}\text { Before } \\
\text { cessation } \\
\text { of diltiazem }\end{array}$ & $\begin{array}{l}\text { ANOVA } \\
p\end{array}$ \\
\hline HR (beat/min) & $62.6 \pm 9$ & $65.1 \pm 7.8$ & $63.1 \pm 7.7$ & $61.7 \pm 7.6$ & $62 \pm 7.8$ & NS \\
\hline $\mathrm{RAP}(\mathrm{mmHg})$ & $8 \pm 6.6$ & $9.1 \pm 5$ & $7 \pm 5.3$ & $8.3 \pm 6.3$ & $8.4 \pm 5.6$ & NS \\
\hline MPAP (mmHg) & $18 \pm 4.4$ & $17.9 \pm 4.6$ & $16.9 \pm 4.1$ & $17.3 \pm 6.1$ & $18.1 \pm 4.6$ & NS \\
\hline PCWP (mmHg) & $10.9 \pm 3$ & $10.7 \pm 4.6$ & $10 \pm 5.1$ & $10.4 \pm 6.1$ & $10.3 \pm 5.3$ & NS \\
\hline$C I\left(L \cdot \min ^{-1} \cdot m^{-2}\right)$ & $2.56 \pm 0.36$ & $2.91 \pm 0.44$ & $2.75 \pm 0.48$ & $2.69 \pm 0.61$ & $2.79 \pm 0.73$ & NS \\
\hline SI $\left(\mathrm{ml} \cdot\right.$ beat $\left.^{-1} \cdot \mathrm{m}^{-2}\right)$ & $41.1 \pm 5.4$ & $44.6 \pm 8.1$ & $43.1 \pm 4.4$ & $42.9 \pm 11.2$ & $44.4 \pm 13.1$ & NS \\
\hline $\begin{array}{l}\text { SVRI } \\
\quad\left(\text { dyne } \cdot \sec \cdot \mathrm{cm}^{-5} \cdot \mathrm{m}^{-2} \text { ) }\right.\end{array}$ & $2234 \pm 498$ & $1810 \pm 330$ & $1969 \pm 582$ & $1800 \pm 564$ & $1608+622$ & NS \\
\hline $\begin{array}{l}\text { PVRI } \\
\qquad\left(\text { dyne } \cdot \sec \cdot \mathrm{cm}^{-5} \cdot \mathrm{m}^{-2} \text { ) }\right.\end{array}$ & $219 \pm 98$ & $200 \pm 78$ & $203 \pm 62$ & $223 \pm 35$ & $248 \pm 61$ & NS \\
\hline Qs/Qt (\%) & $16.9 \pm 5.1$ & $15.6 \pm 5$ & & $18.2=8.4$ & & NS \\
\hline
\end{tabular}

TABLE IV Haemodynamic course during nitroprusside infusion (mean values \pm SD)

\begin{tabular}{|c|c|c|c|c|c|c|}
\hline & \multirow[b]{2}{*}{$\begin{array}{l}\text { Baseline } \\
\text { (lateral } \\
\text { position) }\end{array}$} & \multicolumn{5}{|c|}{ Nitroprusside infusion } \\
\hline & & $+15 \min$ & $+45 \min$ & $\begin{array}{l}\text { Before } \\
\text { cementing }\end{array}$ & $\begin{array}{l}\text { Before } \\
\text { cessation of } \\
\text { nitroprusside }\end{array}$ & $\begin{array}{l}\text { ANOVA } \\
p\end{array}$ \\
\hline HR (beat/min) & $70.9 \pm 8.4$ & $73.3 \pm 11.0$ & $80.2 \pm 15.4$ & $82.1 \pm 18.4$ & $74.7 \pm 15.2$ & NS \\
\hline RAP (mmHg) & $5.1 \pm 2.7$ & $5 \pm 3.3$ & $5.2 \pm 3.7$ & $4.1 \pm 4.8$ & $5.6 \pm 4.8$ & NS \\
\hline MPAP (mmHg) & $16.6 \pm 4.5$ & $14.9 \pm 3.6$ & $16 \pm 3.3$ & $14.9 \pm 3.8$ & $19.7 \pm 3.3$ & NS \\
\hline PCWP (mmHg) & $8.7 \pm 3.2$ & $8.1 \pm 4.7$ & $9.5 \pm 3.4$ & $8.2 \pm 4.6$ & $9.9 \pm 5.3$ & NS \\
\hline $\mathrm{Cl}\left(\mathrm{L} \cdot \mathrm{min}^{-1} \cdot \mathrm{m}^{-2}\right)$ & $2.36 \pm 0.59$ & $3.13 \pm 0.90^{*}$ & $3.76 \pm 1.46^{* *}$ & $3.34 \pm 1.21^{*}$ & $2.92 \pm 0.79 *$ & $<0.05$ \\
\hline SI $\left(\mathrm{ml} \cdot\right.$ beat $\left.^{-1} \cdot \mathrm{m}^{-2}\right)$ & $32.9 \pm 6.4$ & $42.2 \pm 9.5$ & $46.3 \pm 13.8$ & $36.9 \pm 20.4$ & $40.6 \pm 13.3$ & NS \\
\hline $\begin{array}{l}\text { SVRI } \\
\qquad\left(\text { dyne } \cdot \sec \cdot \mathrm{cm}^{-3} \cdot \mathrm{m}^{-2}\right)\end{array}$ & $2752 \pm 512$ & $1455 \pm 371^{* *}$ & $1240 \pm 355 \dagger$ & $1414 \pm 444^{* *}$ & $1783 \pm 230^{*}$ & $<0.01$ \\
\hline $\begin{array}{l}\text { PVRI } \\
\qquad \text { (dyne } \cdot \sec \cdot \mathrm{cm}^{-5} \cdot \mathrm{m}^{-2} \text { ) }\end{array}$ & $254 \pm 77$ & $181 \pm 79$ & $128 \pm 41^{*}$ & $165 \pm 43$ & $190 \pm 82$ & $<0.05$ \\
\hline Qs/Qt (\%) & $13.6 \pm 3.4$ & $21.4 \pm 8.9$ & & $21.9 \pm 6.8^{*}$ & & $<0.05$ \\
\hline
\end{tabular}

Paired $t$ test $v s$ lateral position. ${ }^{*} \mathrm{p}<0.05 . \quad \dagger_{\mathrm{p}}<0.02 . \quad{ }^{* *} \mathrm{p}<0.01$.

Diltiazem seems to be poorly adapted to the technique of controlled hypotension, contrary to the statement of Griffin et al. ${ }^{13}$ who studied dogs anaesthetized with fentanyl. The dose of diltiazem (30 to $90 \mu \mathrm{g} \cdot \mathrm{kg}^{-1} \cdot \mathrm{min}^{-1}$ ) necessary to obtain a significant drop in systemic vascular resistance (from $3249 \pm 257$ to $1138 \pm 148 \mathrm{dyne} \cdot \mathrm{sec} \cdot \mathrm{cm}^{-5}$. $\mathrm{m}^{-2}$ ) were accompanied by electrophysiological modifications (five of six dogs developed first-degree AV block and four of these five dogs developed 2nd-degree AV block); ${ }^{13}$ two dogs had episodes of junctional rhythm. ${ }^{13}$ Furthermore negative chronotropic effects appear to be dose-related and $\mathrm{HR}$ decreased from $109 \pm 6.1$ to $90 \pm 13$ beats $/ \mathrm{min}^{13}$ In our study smaller doses $\left(12.5 \pm 3 \mu \mathrm{g} \cdot \mathrm{kg}^{-1}\right.$. $\mathrm{min}^{-1}$ ) led also to bradycardia and junctional rhythm. However, cardiac index increased (from $2.40 \pm 0.20$ to $4.93 \pm 0.89 \mathrm{~L} \cdot \mathrm{min}^{-1} \cdot \mathrm{m}^{-2}$ ) due to the reduction in afterload, while the $\mathrm{dp} / \mathrm{dt}$ was little modified. ${ }^{13}$ 
In our study smaller doses resulted in a smaller decrease in SVRI ( -28 per cent $v s-65$ per cent in the study of Griffin et al.) and per se in no increase in $\mathrm{CI}$. Hypotension provoked by diltiazem does not seem, therefore, to be linked to myocardial depression, contrary to what is observed in swine anaesthetized with halothane. ${ }^{23}$ Kates et al. ${ }^{23}$ demonstrated that blood pressure is reduced by decreasing cardiac output ( -42 per cent) without affecting systemic vascular resistance. The hypotensive mechanism appears to be different with anaesthesia using fentanyl, since in the absence of modifications in the conditions of ventricular load, the stroke volume and cardiac output are not modified, despite a known-negative inotropic action. ${ }^{24-26}$

In conclusion, arterial pressure is difficult to control with diltiazem and the added depression of AV conduction make its use in controlled hypotension during anaesthesia with fentanyl undesirable. On the other hand, diltiazem provides no harmful effects on cardiac output and produces excellent haemodynamic stability during the recovery period.

\section{Acknowledgements}

We thank Ms. Françoise Bodinier, RN, Mr. Bertrand Lebreton, RN, Ms. Patricia Prouteau, RN, Ms. Marie Paule Lebourdonnec, RN, and Ms. Monique Gouello, RN, for their technical assistance. We are indebted to Dausse Laboratory, Paris, France, for supplies of diltiazem.

\section{References}

1 Thompson GE, Miller RD, Stevens WC, Murray $W R$. Hypotensive anesthesia for total hip arthroplasty: a study of blood loss and organ functions (brain, heart, liver and kidney). Anesthesiology 1978; 48: 91-6.

2 Barbier-Böhm G, Desmonts JM, Couderc E, Moulin $D$, Prokacimer $P$, Olivier $H$. Comparative effects of induced hypotension and normovolemic haemodilution on blood loss in total hip arthroplasty. Br J Anaesth 1980; 52: 1039-43.

3 Cohn JN, Burke LP. Nitroprusside. Ann Intern Med 1979; 91: 752-7.

4 Tinker JH, Michenfelder JD. Sodium nitroprusside: pharmacology, toxicology and therapeutics. Anesthesiology 1976; 45: 340-54.

5 Flacke JW, Flacke WE, Cant JW. Reflex responses to sodium nitroprusside and their control by cryptenamine. Anesth Analg 1980; 59: 909-16.
6 Khambatta HG, Stone JG, Khan E. Hypertension during anesthesia on discontinuation of sodium nitroprusside induced hypotension. Anesthesiology 1979; 51: 127-30.

7 Lam AM. Induced hypotension. Can Anaesth Soc J 1984; 31: S56-S62.

8 Mizgala $H F$. The calcium channel blockers: pharmacology and clinical applications. Can Anaesth Soc J 1983; 30: S5-S10.

9 Cottrel JE, Giffin JP, Hartung J, Shwiry $B$. Intracranial pressure during nifedipine-induced hypotension in cats. Anesth Analg 1983; 62: 254.

10 Oates $H F$. Hypotensive actions of nitroprusside and verapamil compared. Anesthesiology 1979; 51: 363-4.

11 Zimpfer M, Fitzal S, Tonczar L. Verapamil as a hypotensive agent during neuroleptanaesthesia. Br J Anaesth 1981; 53: 885-9.

12 Hung JH, Fukunaga AF, Olewine $S K$, Van Etten A. Hemodynamic, metabolic and hormonal changes following diltiazem-induced hypotension. Anesthesiology 1983; 59:A20.

13 Griffin RM, Dimich I, Pratilas V, Jurado R, Kaplan $J A$. Cardiovascular effects of diltiazem infusion during fentanyl anesthesia. Anesth Analg 1985; 64: 223.

14 Casthely $P A$, Villanueva $R$, Robinowilz $L$, Gandhi $P$, Litwak $B$. Fyman $P N$. Intrapulmonary shunting during deliberate hypotension with nifedipine, diltiazem and labetalol in dogs. Can Anaesth Soc J 1985; 32: 119-23.

15 Britt BA. Diltiazem. Can Anaesth Soc J 1985; 32: 30-44.

16 Reves JG. The relative hemodynamic effects of $\mathrm{Ca}^{++}$entry blockers. Anesthesiology 1984; 61: 3-5.

17 Valette H, Barnay C, Lopez $M$ et al. Effects of intravenous diltiazem on sinus node function and atrioventricular conduction in patients. J Cardiovasc Pharmacol 1983; 5; 62-6.

18 Morselli PL, Rovei V, Mitchard M. Pharmacokinetics and metabolism of diltiazem in man. $I n$ : New drug therapy with a calcium antagonist, diltiazem. Hakone Symposium 1978; pp. 152-68. Bing, RJ. Ed. Excerpta Medica. Amsterdam, 1978.

19 Fujimoto T, Peter T, Mandell WJ. Electrophysiologic and hemodynamic actions of diltiazem disparate temporal effects shown by experimental dose-response studies. Am Heart J 1981; 101: 403-7. 
20 Browne RK, Dimmitt DC, Miller LD, Korol B. Relationship between plasma diltiazem and cardiovascular responses in conscious dogs. J Cardiovasc Pharmacol 1983; 5: 483-90.

21 Pierrot $M$, Blaise $M$, Hugon $S$, Bonnet $F, C$ Cupa $M$. Interférences hémodynamiques entre le diltiazem et le thiopental. Etude expérimentale chez le porc. Can Anaesth Soc J 1984; 31: 166-72.

22 Bourassa MG, Cote P, Theroux P, Tubau JF, Genain $C$, Waters $D D$. Hemodynamics and coronary flow following diltiazem administration in anesthetized dogs and in humans. Chest 1980; 78: 224-30 (suppl).

23 Kates RA, Zaggy AP, Norfleet EA, Heath KR. Comparative cardiovascular effets of verapamil, nifedipine and diltiazem during halothane anesthesia in swine. Anesthesiology 1984; 61: 10-8.

24 Uchida $Y$. Effect of diltiazem, a new anti-Ca ${ }^{++}$ agent, on left ventricular function in patients with and without angina pectoris. A study using ultrasonic analogue conversion system. Jpn Heart J 1976; 599-610.

25 Perez JE, Sobel BE, Henry PD. Improved performance of ischemic canine myocardium in response to nifedipine and diltiazcm. Am J Physiol 1980; 239: H658-63.

26 Walsh RA, Badke FR, O'Rourke RA. Differential effects of systemic and intracoronary calcium channel blocking agents on global and regional left ventricular function in conscious dogs. Am Heart J 1981; 102: 341-50.

\section{Résumé}

Le diltiazem a été testé comparativement au nitro. prussiate de sodium pour provoquer une hypotension contrólée au cours des arthroplasties de hanche $(n=14)$. Les données hémodynamiques ont été recueillies sous anesthésie générale (thiopental - fentanyl - pancuranium) en décubitus latéral avant, pendant et après administration de l'agent hypotenseur (choix randomisé). Le diliazem (bolus IV de $0.15 \mathrm{mg} \cdot \mathrm{kg}^{-1}$ suivi d' une perfusion continue de $12.5 \pm 3 \mu \mathrm{g} \cdot \mathrm{kg}^{-1} \cdot \mathrm{min}^{-1}$ ) a entraíné une baisse de pression artérielle moyenne (PAM) de $77 \pm 11$ $\mathrm{mmHg}$ à $63 \pm 16 \mathrm{mmHg}(p<0.05)$ sans modifications significatives des autres données hémodynamiques, L'hypotension s'est maintenue au moins 30 min après arrêt du diltiazem. Le nitroprussiate de sodium a entraîné une baisse immédiate de PAM de $81 \pm 11 \mathrm{mmHg}$ a $59 \pm 9$ $m m H g(p<0.01)$; le retour de PAM à la valeur contrôle est obtenue rapidement après arrêt du nitroprussiate. $L$ 'index cardiaque et $Q s / Q t$ se sont élevés significativement $(p<0.05)$ alors que l'index des résistances vasculaires systémiques (RVS) $(p<0.01)$ et l'index des résistances vasculaires pulmonaires $(R V P)(p<0.05)$ se sont abaissés significativement. Ces profils hémodynamiques ont été significativement différents pour la MAP $(p<0.02)$, la fréquence cardiaque $(F C)(p<0.01)$, les RVS $(p<0.05)$ et les RVP ( $p<0.05)$. FC a étéplus basse sous diltiazem que sous nitroprussitate; une bradycardie inférieure d̀ SOlmin a été observée chez cinq des sept patients. PAM, RVS et RVP ont été plus basses sous nitroprussiate que sous diltiazem. Le diltiazem est susceptible d'induire, de maintenir une hypotension sans tachycardie et sans diminution du débit cardiaque chez l'homme pendant une anesthésie au fentanyl, mais, la modulation du niveau d' hypotension et la dépression de la conduction auriculo-ventriculaires sont imprévisibles. 